\title{
AUDIT KEAMANAN SISTEM INFORMASI AKADEMIK MENGGUNAKAN FRAMEWORK NIST SP 800-26 (Studi Kasus : Universitas Sangga Buana YPKP Bandung)
}

\author{
JUNAIDI AKROM \\ 195100013P \\ Fakultas Ilmu Komputer, Universitas Mitra Indonesia \\ junaidiakrom.student@umitra.ac.id
}

\begin{abstract}
ABSTRAK
Persaingan diantara lembaga pendidikan semakin terasa. Informasi yang disediakan oleh lembaga tersebut pun harus dapat dirasakan dengan cepat, tepat dan dapat dipercaya oleh konsumen. Perkembangan teknologi informasi yang diterapkan di dunia pendidikan memiliki dampak yang positif. Semakin berkembangnya teknologi informasi, semakin terasa pula peran yang diberikan oleh teknologi informasi tersebut. Namun, akibat perkembangan teknologi informasi tersebut membuat tingkat keamanan sebuah sistem informasi menjadi sangat rentan. Untuk itu, perlu dilakukan identifikasi terhadap keamanan pada sistem informasi tersebut. Jika audit keamanan tidak dilakukan, maka akan terjadi masalah pada sistem informasi tersebut, beberapa masalah yang mungkin terjadi adalah hilangnya data data akan menjadi tidak valid, akurasi data menjadi tidak dapat dipercaya,dan sistem informasi tersebut akan menjadi rentan terhadap ancaman. Audit keamanan dapat dilakukan dengan menggunakan standar kerangka kerja. NIST merupakan salah satu kerangkan kerja yang biasa digunakan mengidentifikasi keamanan dan resiko pada sistem informasi. Proses penilaian audit keamanan sistem informasi dilakukan dengan menyebarkan kuesioner berdasarkan framework NIST SP 800-26 dan data tersebut dikelola untuk mendapatkan hasil akhirnya. Hasil audit keamanan sistem informasi akademik dengan framework NIST SP 800-26 menunjukkan bahwa keamanan pada sistem informasi akademik tersebut memiliki nilai secara keseluruhan sebesar $72.43 \%$. Nilai tersebut didapat dari hasil perhitungan berdasarkan 3 (tiga) kategori yang diuji, yaitu pengendalian manajemen (management control), pengendalian operasional (operational control), pengendalian teknikal (technical control). Berdasarkan data tersebut, keamanan sistem informasi yang ada di Unviersitas Sangga Buana YPKP termasuk ke dalam level 3, yaitu implemented procedures and controls.
\end{abstract}

Kata Kunci : Audit Keamanan, Sistem Informasi Akademik, NIST SF 800-26, Kuesioner

\section{PENDAHULUAN 1.1 Latar Belakang}

Akhir - akhir ini, persaingan diantara lembaga pendidikan semakin terasa. Sehingga, membuat para pimpinan lembaga pendidikan, khususnya perguruan tinggi harus bisa memenuhi tuntuntan masyarakat terkait kualitas lulusan dan layanan. Kemampuan meningkatkan kualitas dan layanan, khususnya kepada masyarakat akan menjadikan lembaga pendidikan tersebut menjadi pemenang dalam persaingan di era kompetisi ini. Salah satu upaya yang dapat dilakukan dalam meningkatkan daya saing lembaga pendidikan, para pimpinan harus bisa menyediakan informasi yang cepat, tepat, dan dapat dipercaya.

Perkembangan teknologi informasi dalam dunia pendidikan memberikan dampak positif. Dengan berkembangnya teknologi informasi, dunia pendidikan mulai memperlihatkan perubahan yang cukup signifikan. Ada perubahan cara-cara mengajar yang berkembang dalam dunia pendidikan. Sekarang ini, jarak dan waktu bukanlah sebagai masalah yang berarti untuk transfer ilmu pengetahuan. Banyak software dan aplikasi yang dibuat untuk memfasilitasi dalam transfer pengetahuan ini. [1]

Tujuan diterapkannya sistem informasi di dunia pendidikan adalah untuk kemudahan dan 
kesempurnaan dalam memberikan pelayanan, informasi yang akurat dan dapat dipercaya, serta menjadikan perguruan tinggi yang memiliki daya saing yang mumpuni untuk bisa bertahan dalam persaingan. Teknologi informasi memiliki peran yang signifikan dalam peningkatan mutu pelayanan dan daya saing suatu organisasi.

NIST merupakan sebuah kerangka kerja yang dipublikasikan oleh National Institute of Standard Technology (NIST). NIST melakukan pengukuran, penetapan standard dan teknologi untuk dapat mengoptimalkan peran dari infrastruktur institusi, khususnya dalam bidang IT. NIST memiliki banyak versi dan topik, namun saling berkaitan. Salah satu versi dari NIST untuk melakukan audit keamanan sistem informasi adalah "NIST Special Publication 800-26:Security SelfAssessment Guide For Information Technology Systems". Kerangka kerja NIST tersebut diharapkan dapat meningkatkan kemampuan sebuah institusi dalam mengatasi pemasalahan keamanan komputer, baik saat ini maupun masa yang akan datang.

\subsection{Rumusan Masalah}

Berdasarkan latar belakang tersebut, maka dirumuskanlah masalah dalam penelitian ini, yaitu bagaimana sistem keamanan yang diterapkan pada sistem informasi akademik di Universitas Sangga Buana YPKP.

\subsection{Tujuan Penelitian}

Tujuan dari penelitian tidak lain adalah untuk menjawab rumusan masalah sebelumnya, yaitu untuk menganalisa sistem keamanan yang diterapkan pada sistem informasi akademik di Universitas Sangga Buana YPKP.

\section{LANDASAN TEORI}

\subsection{Sistem Informasi}

Sistem informasi adalah suatu sistem di dalam suatu organisasi yang mempertemukan kebutuhan pengolahan transaksi harian mendukung operasi, bersifat manajerial dan kegiatan strategis dari suatu organisasi dan menyediakan pihak luar tertentu dengan laporanlaporan yang dibutuhkan. ${ }^{[2]}$

Sistem informasi dapat didefinisikan sebagai kumpulan elemen-elemen atau sumber daya dan jaringan prosedur yang saling berkaitan secara terpadu, terintegrasi dalam suatu hubungan hirarkis tertentu, dan bertujuan untuk mengolah data menjadi informasi. ${ }^{[3]}$ Sistem informasi pada umumnya dapat terbentuk dengan beberapa kegiatan operasi, yaitu. ${ }^{[4]}$

1. Pengumpulan data

2. Pengelompokkan data

3. Penghitungan data

4. Analisa topik data

5. Penyajian laporan

\subsection{Komponen Sistem Informasi}

Sistem informasi terdiri dari komponen- komponen yang disebut dengan istilah Building Block, yaitu. ${ }^{[5]}$

[1]. Blok masukan (Input Block) Input mewakili data yang masuk ke dalam sistem informasi.

[2]. Blok model (Model Block) Blok ini terdiri dari kombinasi prosedur, logika, dan metode matematika yang akan memanimpulasi data input.

[3]. Blok keluaran (Output Block) Produk dari sistem informasi adalah informasi yang berkualitas dan terdokumentasi yang berguna untuk semua tingkatan manajemen.

[4]. Blok teknologi (Technology Block) Teknologi digunakan 
untuk melakukan semua proses yang ada pada sistem informasi.

[5]. Blok basis data (Database Block) Kumpulan data yang berhubungan antara satu dengan yang lainnya, tersimpan di perangkat keras komputer dan menggunakan perangkat lunak untuk memanipulasinya.

[6]. Blok kendali (Control Block) Beberapa pengendalian perlu dirancang dan diterapkan untuk meyakinkan bahwa hal-hal yang dapat merusak sistem dapat dicegah atau bila terlanjur terjadi kesalahan dapat langsung diatasi. 


\subsection{Sistem Informasi Akademik}

Sistem informasi akademik merupakan cara yang terorganisir, untuk mengumpulkan, memasukkan dan memproses datadan menyimpannya, mengelola, mengontrol dan melaporkannya sehingga dapat mendukung perusahaan atau organisasi untuk mencapai tujuan. ${ }^{[6]}$

Sistem informasi akademik adalah perangkat lunak yang digunakan untuk menyajikan informasi dan menata administrasi yang berhubungan dengan kegiatan akademis. $^{[7]}$

Pengelolaan data bidang studi dan kurikulum mempermudah pencarian informasi akan salah satu bidang studi. Penyajian yang baik dalam klasifikasi (kriteria) tertentu dan menarik (meskipun tetap formal) akan dapat menampung data yang lebih besar dan menghasilkan informasi yang lebih berguna. Jika cara ini dipilih, sejumlah informasi tambahan seharusnya dapat disertakan atau diberikan link ke perguruan tinggi penyelenggara. Misalnya tentang dosen pengajar dan perbedaan/persamaan materi. Secara terdistribusi, data dikelola oleh masing-masing, tetapi ada gateway ataupun penyajian yang disepakati bersama untuk kemudahan pembaca. Departemen pendidikan ataupun pemerintah juga memperoleh hak akses. Bila diperlukan, pengumpulan data untuk arsip dapat dilakukan melalui internet setiap saat dan mengurangi kebutuhan pertukaran data melalui media cetak (paperless). Kegiatan perkuliahan dilakukan setiap semester mencakup: a) pendaftaran peserta kuliah pada semester yang akan berlangsung; b) perkuliahan yang sedang berjalan, yaitu materi dan tugas; c) ujian atau evaluasi atas hasil perkuliahan. ${ }^{[8]}$

\subsection{Keamanan Sistem Informasi}

Keamanan sistem informasi merupakan hal yang perlu diperhatikan saat membangun sebuah sistem informasi. Bayangkan kita membuat sebuah rumah yang lengkap dengan jendela dan pintu, tetapi kita tidak membuat kunci untuk pintu dan jendela. Hal ini dapat menyebabkan seseorang dengan mudah memasuki rumah kita, bahkan mungkin melakukan pencurian. Sama halnya dengan membangun sistem informasi, keamanan sistem informasi digunakan untuk menghindari seseorang yang tidak memiliki akses untuk dapat masuk ke dalam sistem. Terdapat 3 hal yang menjadi aspek penilaian audit keamanan sistem informasi, yaitu confidentiality (kerahasiaan), integrity (integritas) dan Availability (ketersediaan). ${ }^{[9]}$

\subsection{Audit Sistem Informasi}

Tujuan dilakukannya audit sistem informasi adalah pengamanan aset, efektifitas sistem, efisiensi sistem, ketersediaan layanan, kerahasiaan, kehandalan, menjaga integritas data. ${ }^{[3]}$

\subsection{NIST SP 800-26}

NIST SP 800-26 mengungkapkan terdapat 17 sub kategori penilaian yang terbagi menjadi 3 kelompok pengendalian yaitu. ${ }^{[10]}$

1. Management Control
a. Risk Management
b. Review of Security Control
c. Life Cycle
d. Authorize Processing
e. System SecurityPlan

2. Operational Control

a. Personnel Security

b. Physical Security

c. Production, Input and Output Control

d. Contingency Planning

e. Hardware and System Software

Maintenance

f. Data Integrity

g. Documentation

h. Security Awareness, Training, and

Education

i. Incident Response Capability

3. Technical Control

a.Identification AndAuthentication

b.Logical Access Control

c. Audit Trails

NIST SP 800-26 pun menyebutkan terdapat 5 tingkatan keamanan pada teknologi informasi, yaitu. ${ }^{[10]}$

1. Tingkat 1 - Documented Policy

(Kebijakan terdokumentasi).

2. Tingkat 2 - Documented Procedures (Prosedur terdokumentasi).

3. Tingkat 3 - Implemented Procedures and Controls (Prosedur dan pengendalian sudah dilakukan). 
4. Tingkat 4 - Tested and Reviewed Procedures and Controls (Prosedur dan pengendalian sudah diuji dan dikaji ulang).

5. Tingkat 5-Fully Integrated Procedures and Controls (Prosedur dan pengendalian sepenuhnya sudah terintegrasi)

\section{OBJEK DAN METODOLOGI}

\subsection{Objek Penelitian}

Objek penelitian yang sudah ditetapkan yaitu Sistem Informasi Akademik yang terdapat di Universitas Sangga Buana YPKP Bandung.

\section{$32 \quad$ Metodologi Penelitian}

Metode penelitian merupakan susunan langkah kerja yang dibuat secara berurutan. Metode penelitian ini adalah sebagai berikut.

1. Persiapan penelitian.

Persiapan Penelitian berupa menentukan latar belakang dan merumuskan masalah.Selain itu, melakukan studi literature danmengkaji teori sebagai landasan teori.

2. Menentukan kriteria dan merancang kuesioner.

Kriteria penilaian ditentukan berdasarkan yang tercantum di dalam framework NIST SP 800-26. Jumlah kriteria yang digunakan sebanyak 17 kriteria yang terbagi ke dalam 3 kelompok pengendalian. Kriteria tersebut digunakan untuk menyusun kuesioner penilaian.

Masing-masing kriteria penilaian memiliki 2 jumlah pernyataan, sehingga total data untuk tiap kriteria berjumlah 80 data dan menggunakan skala Likert (skala penilaian 1-5).

3. Menentukan responden.

Responden yang ditunjuk adalah struktural rektorat, fakultas, dan prodi. Struktural rektorat terdiri dari rektor beserta jajarannya, biro akademik, keuangan, kepegawaian, dan direktur PUDI beserta staffnya. responden dari pihak fakultas yaitu dekan fakultas dan responden dari program studi yaitu kepala bagian program studi. Jumlah responden secara keseluruhan berjumlah 40 orang.

4. Analisa Data dan Pembahasan.
Data yang didapat dari responden melalui kuesioner yang disebar kemudian di analisa dan dilakukan pembahasan untuk dapat menarik kesimpulan terkait kondisi objek penelitian.

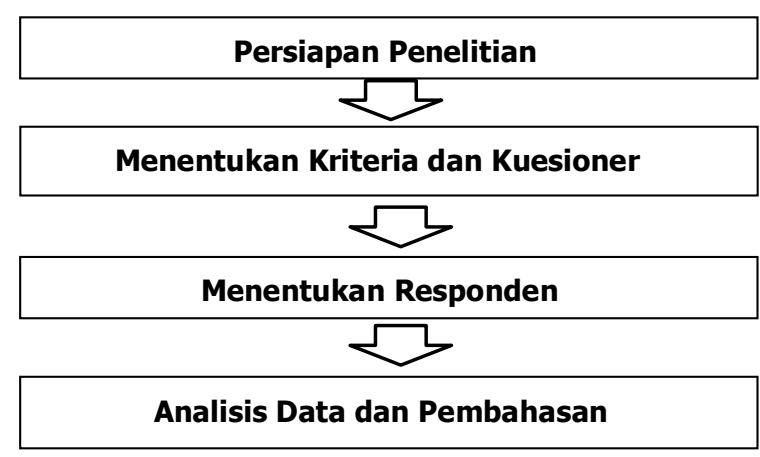

Gambar 1. Tahapan Penelitian

\section{HASIL DAN PEMBAHASAN}

\subsection{Hasil Penelitian}

Hasil penelitian ini berupa data kuesioner yang didapat dari penilaian 40 orang responden. Data tersebut diolah untuk mendapatkan hasil akhir penilaian.

\subsubsection{Penilaian Management Control}

Tabel 1. Penilaian Management Control

\begin{tabular}{|c|c|c|c|c|}
\hline No. & Kriteria & $\begin{array}{c}\text { Rata- } \\
\text { rata }\end{array}$ & $\begin{array}{c}\text { Rata- } \\
\text { rata } \\
\text { Akhir }\end{array}$ & $\begin{array}{c}\text { Persentase } \\
(\%)\end{array}$ \\
\hline 1 & 1.a & 3,6125 & \multirow{5}{*}{3,5425} & \multirow{5}{*}{70,85} \\
\hline 2 & $1 . b$ & 3,6500 & & \\
\hline 3 & 1.c & 3,5750 & & \\
\hline 4 & 1.d & 3,4000 & & \\
\hline 5 & 1.e & 3,4750 & & \\
\hline
\end{tabular}

Berdasarkan perhitungan data kuesioner tersebut, hasil penilai untuk penilaian management control berada pada angka 3,5425 dari 5. Merujuk pada tingkatan keamanan sistem informasi yang terdapat di dalam framework NIST SP 800-26 yang digunakan, management controls berada pada tingkat 3 , yaitu implemented procedures and controls. Itu artinya, prosedur dan pengendalian yang direncanakan oleh pihak institusi, yang berkaitan dengan management control sudah dijalankan. 
4.1.2 Penilaian Operational Control

Tabel 2. Penilaian Operational Control

\begin{tabular}{|c|c|c|c|c|}
\hline No. & Kriteria & $\begin{array}{l}\text { Rata- } \\
\text { rata }\end{array}$ & $\begin{array}{c}\text { Rata-rata } \\
\text { Akhir }\end{array}$ & $\begin{array}{c}\text { Persentase } \\
(\%)\end{array}$ \\
\hline 1 & 2.a & 3,5375 & \multirow{9}{*}{3,5972} & \multirow{9}{*}{71,94} \\
\hline 2 & 2.b & 3,4750 & & \\
\hline 3 & $2 . c$ & 3,4500 & & \\
\hline 4 & 2.d & 3,6250 & & \\
\hline 5 & 2.e & 3,9250 & & \\
\hline 6 & 2.f & 3,6375 & & \\
\hline 7 & $2 . \mathrm{g}$ & 3,6000 & & \\
\hline 8 & $2 . h$ & 3,5875 & & \\
\hline 9 & $2 . \mathrm{i}$ & 3,5375 & & \\
\hline
\end{tabular}

Berdasarkan perhitungan data kuesioner tersebut, hasil penilai untuk penilaian management control berada pada angka 3,5972 dari 5. Merujuk pada tingkatan keamanan sistem informasi yang terdapat di dalam framework NIST SP 800-26 yang digunakan, management controls berada pada tingkat 3, yaitu implemented procedures and controls. Itu artinya, prosedur dan pengendalian yang direncanakan oleh pihak institusi, yang berkaitan dengan operational control sudah dijalankan.

\subsubsection{Penilaian Technical Control}

Tabel 3. Penilaian Technical Control

\begin{tabular}{|c|c|c|c|c|}
\hline No. & Kriteria & $\begin{array}{c}\text { Rata- } \\
\text { rata }\end{array}$ & $\begin{array}{c}\text { Rata- } \\
\text { rata } \\
\text { Akhir }\end{array}$ & $\begin{array}{c}\text { Persentase } \\
(\%)\end{array}$ \\
\hline 1 & $3 . \mathrm{a}$ & 3,6625 & \multirow{2}{*}{3,6917} & \multirow{2}{*}{73,83} \\
\hline 2 & $3 . \mathrm{b}$ & 3,6750 & \multirow{2}{*}{3,6917} & \\
\hline 3 & 3.c & 3,7375 & & \\
\hline
\end{tabular}

Berdasarkan perhitungan data kuesioner tersebut, hasil penilai untuk penilaian management control berada pada angka 3,6917 dari 5. Merujuk pada tingkatan keamanan sistem informasi yang terdapat di dalam framework NIST SP 800-26 yang digunakan, management controls berada pada tingkat 3, yaitu implemented procedures and controls. Itu artinya, prosedur dan pengendalian yang direncanakan oleh pihak institusi, yang berkaitan dengan technical control sudah dijalankan.

\subsubsection{Penilaian Keseluruhan}

Tabel 4. Penilaian Keseluruhan

\begin{tabular}{|c|c|c|c|c|}
\hline $\begin{array}{c}\text { No } \\
\text {. }\end{array}$ & $\begin{array}{c}\text { Kriteria } \\
\text { Pengendalia } \\
\text { n }\end{array}$ & $\begin{array}{c}\text { Rata- } \\
\text { rata }\end{array}$ & $\begin{array}{l}\text { Rata- } \\
\text { rata } \\
\text { Akhir }\end{array}$ & $\begin{array}{c}\text { Persentas } \\
\mathrm{e} \\
(\%)\end{array}$ \\
\hline 1 & 1 & $\begin{array}{c}3,542 \\
5\end{array}$ & \multirow{3}{*}{$\begin{array}{c}3,700 \\
5\end{array}$} & \multirow{3}{*}{72,43} \\
\hline 2 & 2 & $\begin{array}{c}3,597 \\
2\end{array}$ & & \\
\hline 3 & 3 & $\begin{array}{c}3,691 \\
7\end{array}$ & & \\
\hline
\end{tabular}

Berdasarkan perhitungan data kuesioner tersebut, hasil penilai untuk penilaian secara keseluruhan berada pada angka 3,7005 dari 5 . Merujuk pada tingkatan keamanan sistem informasi yang terdapat di dalam framework NIST SP 800-26 yang digunakan, management controls berada pada tingkat 3 , yaitu implemented procedures and controls. Itu artinya, prosedur dan pengendalian yang direncanakan oleh pihak institusi secara keseluruhan sudah dijalankan.

\subsubsection{Validitas Data}

Validitas suatu alat ukur didefinisikan sebagai sifat suatu ukuran yang memungkinkan peneliti beranggapan bahwa alat ukur itu dapat digunakan untuk mengukur karakter yang hendak diukurnya. Validitas adalah suatu ukuran yang menunjukkan tingkat keakuratan alat ukur. Suatu alat ukur dinyatakan valid jika alat ukur itu menghasilkan ukuran yang tepat dalam suatu pengukuran masalah tertentu, dan tidak valid untuk mengukur masalah lain. Alat ukur yang valid dan akurat mempunyai validitas yang tinggi, sebaliknya alat ukur yang kurang valid memiliki validitas yang rendah. Pada umumnya, validitas alat ukur bergantung pada faktor logika dan pembuktian statistik. ${ }^{[11]}$ Penentuan validitas data pada penelitian ini menggunakan aplikasi Microsoft Excel. Hal tersebut bertujuan untuk memudahkan dalam proses pengolahan datanya.

Tabel 5.Validitas Data Kuesioner

\begin{tabular}{|c|c|c|}
\hline No. & Kriteria & Validitas \\
\hline 1 & $1 . \mathrm{a}$ & Valid \\
\hline 2 & $1 . \mathrm{b}$ & Valid \\
\hline 3 & $1 . \mathrm{c}$ & Valid \\
\hline 4 & $1 . \mathrm{d}$ & Valid \\
\hline 5 & $1 . \mathrm{e}$ & Valid \\
\hline
\end{tabular}




\section{Section 01}

\begin{tabular}{|c|c|c|}
\hline 6 & $2 . \mathrm{a}$ & Valid \\
\hline 7 & $2 . \mathrm{b}$ & Valid \\
\hline 8 & $2 . \mathrm{c}$ & Valid \\
\hline 9 & $2 . \mathrm{d}$ & Valid \\
\hline 10 & $2 . \mathrm{e}$ & Valid \\
\hline 11 & $2 . \mathrm{f}$ & Valid \\
\hline 12 & $2 . \mathrm{g}$ & Valid \\
\hline 13 & $2 . \mathrm{h}$ & Valid \\
\hline 14 & $2 . \mathrm{i}$ & Valid \\
\hline 15 & $3 . \mathrm{a}$ & Valid \\
\hline 16 & $3 . \mathrm{b}$ & Valid \\
\hline 17 & $3 . \mathrm{c}$ & Valid \\
\hline
\end{tabular}

\section{PENUTUP}

Berdasarkan hasil penilaian audit keamanan terhadap sistem informasi akademik yang terdapat di Universitas Sangga Buana YPKP, dapat disimpulkan bahwa sistem informasi akademik tersebut sudah berada pada tingkat 3, yaitu implemented procedures and controls. Itu menandakan bahwa prosedur dan pengendalian yang ditetapkan oleh pihak institusi sudah dijalankan. Hal tersebut didapat berdasarkan hasil penilaian audit keamanan secara keseluruhan yang berada pada angka 3,7005 dari 5.

\section{DAFTAR PUSTAKA}

[1]. Dede Yahya, Perkembangan Teknologi Informasi dan Komunikasi di Bidang Pendidikan Indonesia. 2011.

[2]. Jogiyanto, Analisa dan Desain Sistem Informasi. Surabaya:Informatika. 2005.

[3]. Sanyoto Gondodiyoto, Audit Sistem Informasi. Jakarta:Mitra Wacana Media. 2007.

[4]. Tata Sutarbi, Sistem Informasi Manajemen. Yogyakarta:Andi. 2005.

[5]. Jeperson Hutahaean, Konsep Sistem Informasi. Yogyakarta:Deepublish. 2014.

[6]. Rudy Tantra, Manajemen Proyek Sistem Informasi. Yogyakarta:Andi. 2012.
[7]. Kodrat Iman Satoto, Analisis Keamanan Sistem Informasi Akademik Berbasis Web di Fakultas Teknik Universitas Diponegoro. Seminar Nasional Aplikasi Sains dan Teknologi. 2008.

[8]. Astin Lukum, Implementasi Sistem Informasi Akademik Universitas Negri Gorontalo. Jurnal Entropi Vol. VIII No. 1. 2013.

[9]. Chalifa Chazar, "Standar Manajemen Keamanan Sistem Informasi Berbasis ISO/IEC 27001:2005”, Jurnal informasi Vol. VII No. 2,2015.

[10]. Marianne Swanson. NIST Special Publication 800-26. Washington:U.S. Government Printing Office. 2001.

[11]. Jusman Iskandar, Metode Penelitian Administrasi. Bandung:Puspaga. 2005 